\title{
Pengurangan Waktu Proses Pembuatan Produk Cap (C1805- 009): Suatu Pendekatan Simulasi
}

\author{
Dhaul Fathoni ${ }^{1}$, Johan Krisnanto Runtuk ${ }^{2}$ \\ 1,2) Jurusan Teknik Industri, Fakultas Teknik President University \\ Jl. Ki Hajar Dewantara \\ Kota Jababeka,Cikarang, Bekasi - Indonesia 17550 \\ Email: ${ }^{1}$ dhaulfathoni7394@gmail.com, johan.runtuk@president.ac.id
}

\begin{abstract}
Abstrak
PT.S adalah perusahaan pengepresan logam yang memproduksi spare part untuk industri otomotif. Semakin bertambahnya perusahaan baru, mendorong perusahaan untuk terus melakukan perbaikan, salah satunya dengan melakukan pengurangan waktu proses. Permasalahan yang terjadi adalah sering terjadinya keterlambatan pulling stock yang berada di area persediaan produk jadi. Salah satunya terjadi pada produk Cap (C1805-009) dalam kurun waktu 6 bulan (Oktober 2017 sampai Maret 2018) terjadi 16 kali kekosongan stok di area persediaan produk barang jadi. Selain itu, adanya peningkatan permintaan mengharuskan perusahaan melakukan berbagai macam cara antara lain dengan menambah empat inspektor di tiap shift. Penelitian ini bertujuan untuk menganalisis tersendatnya aliran proses produksi dan pemborosan waktu dengan pendekatan simulasi. Berdasarkan hasil simulasi menggunakan software Promodel, diketahui bahwa stasiun kerja yang menjadi penyebab kemacetan aliran yaitu stasiun kerja inspeksi. Usulan perbaikan hasil simulasi juga menunjukkan perbaikan yaitu pengurangan waktu proses sebesar $330,66 \%$ dan pengurangan jumlah operator sebesar $50 \%$. Hasil simulasi ini dapat menjadi pertimbangan PT. S untuk memperlancar aliran proses pembuatan produk Cap (C1805-009).
\end{abstract}

Kata kunci: waktu proses, kemacetan aliran, pemborosan, simulasi.

\begin{abstract}
PT.S is a metal pressing company that produces spare parts for the automotive industry. The increasing number of new companies, encouraging the company to make improvements continously, one of which is by reducing the processing time. The problem that occurs is the frequent occurrence of late pulling stocks in the finished product inventory area. One of them occurs in the Cap product (C1805-009) within a period of 6 months (October 2017 to March 2018) 16 times the stockout in the finished product inventory area. In addition, an increase in demand requires companies to do various ways, including adding four inspectors on each shift. This study aims to analyze the flow of production processes and waste of time with a simulation approach. Based on the simulation results using the Promodel software, it is known that the work station that is the cause of flow congestion is the inspection work station. Proposed improvements in simulation results also showed improvements, namely the reduction of processing time by $330.66 \%$ and the reduction in the number of operators by $50 \%$. The simulation results can be considered by PT. S to improve the flow of the Cap product manufacturing process (C1805-009).
\end{abstract}

Keywords: processing time, bottleneck flow, waste, simulation.

\section{Pendahuluan}

PT. S adalah perusahaan pengepresan logam yang memproduksi komponen kendaraan khususnya untuk komponen mobil Perusahaan ini berlokasi di kawasan industri jababeka kabupaten Bekasi. Permasalahan yang terjadi di PT. S adalah sering terjadinya keterlambatan pulling stock yang berada di area persediaan produk jadi. Salah satunya terjadi pada produk Cap (C1805-009) dalam kurun waktu 6 bulan (Oktober 2017 sampai Maret 2018) terjadi 16 kali kekosongan stok di area persediaan produk barang jadi. Kuantitas rata - rata pemesanan pada produk Cap (1805-009) ini mencapai 1.000.000 pcs tiap bulan. Tingginya permintaan mengharuskan perusahaan melakukan berbagai macam cara antara lain dengan menambah empat inspektor di tiap shift. Banyaknya inspektor merupakan pemborosan karena secara teori sendiri inspektor tidak meningkatkan nilai jual dari produk. Perbedaan lama waktu proses antar stasiun kerja mengakibatkan tersendatnya aliran proses produksi, penumpukan material 
yang menunggu proses, maupun operator yang menunggu kedatangan material yang akan diproses. Pemborosan yang lain terjadi karena jarak antar stasiun kerja yang jauh sehingga memerlukan waktu pemindahan yang lama.

Berdasarkan permasalahan diatas maka perlu dilakukanya analisis untuk mengetahui penyebab kemacetan aliran proses, menurunkan waktu produksi, memnyeimbangkan aliran proses produksi, mengurangi pemborosan jumlah inspektor tetapi tidak menimbulkan keterlambatan pulling stock pada di PT.S. Pada penelitian ini, analisis dan usulan perbaikan proses dilakukan dengan pendekatan simulasi.

\section{Kajian Pustaka}

Tujuan industri manufaktur menurut Mabert dan Jacob (1991) yaitu: (1) memproduksi barang barang yang berkualitas tinggi, (2) mempertahankan pengiriman barang tepat waktu, (3) meningkatkan produktivitas untuk meningkatkan harga jual produk, (4) memiliki sistem manufaktur yang fleksibel. Tujuan tersebut dapat tercapai salah satunya oleh karena sistem produksi yang efektif dan efisien. Sistem produksi tersebut tidak tercipta bukan hanya oleh adanya teknologi yang canggih, namun juga oleh adanya metode kerja yang tepat. Oleh karena itu, perbaikan metode kerja harus terus diupayakan oleh perusahaan.

Perbaikan metode kerja adalah perbaikan dari tahapan-tahapan proses pekerjaan, jalan yang akan ditempuh, cara yang akan dilakukan untuk mencapai suatu tujuan. Tahapan untuk perbaikan metode kerja dilakukan dengan analisa metode untuk mencari, mengembangkan, serta menerapkan metode yang lebih efektif dan efisien (Wignjoesoebroto, 1992). Secara umum, perbaikan metode kerja fokus pada pemborosan. Shingo (1990) menyatakan ada tujuh pemborosan dalam proses produksi, yaitu: menunggu, produksi berlebihan, transportasi berlebihan, kesalahan proses, persediaan berlebihan, dan cacat.

Selain perbaikan metode kerja, kelancaran proses produksi juga dipengaruhi oleh tata letak di perusahaan. Perancangan kembali tata letak adalah sebuah perubahan kecil dalam suatu penataan tata ruang, dengan tujuan meminimumkan biaya dan meningkatkan efisiensi penggunaan segala sesuatu dalam penataan tata ruang. Hal ini termasuk penataan kerja operator, pemindahan material, operasi gudang, dan alat pendukung lain sehingga mencapai tata letak yang baik di perusahaan.

Mengingat sulitnya dan mahalnya untuk melakukan eksperimen langsung terkait perbaikan proses, maka pendekatan simulasi menjadi jalan keluar yang baik. Salah satu software simulasi yang umum digunakan untuk simulasi proses manufaktur adalah software Promodel. Simulasi Promodel adalah alat simulasi yang dapat digunakan untuk mensimulasikan variasi model manufaktur dan sistem layanan. Sistem manufaktur seperti job order, koveyor, transfer lini, produksi masal, lini perakitan, sistem manufaktur yang fleksibel, crane, sistem produksi just in time, sistem kanban, dan sebagainya (Harrel, 2012).

\section{Hasil dan Pembahasan}

\subsection{Waktu Proses di Stasiun Kerja}

Aliran proses di PT. S dapat disederhanakan ke dalam tiga proses, yaitu proses di incoming material, proses di statisun pengepresan, dan proses di stasiun inspeksi. Waktu proses pada setiap stasiun kerja yang dilewati proses produksi produk Cap (C1805-009) ditunjukkan pada Tabel 1.

Aliran proses dimulai dari material masuk dan disimpan di area incoming selanjutnya proses pengepresan yang merubah material coil menjadi material WIP (work in proses). Material WIP (work in proses) masuk stasiun kerja inspeksi dan keluar menjadi produk jadi (finish good). Kemudian produk jadi (finish good) disimpan diarea store finish good menunggu jadwal pengiriman ke pelanggan.

Berdasarkan data tersebut dapat disimpulkan bahwa waktu rata - rata penyelesaian untuk satu box, dengan kuantitas 2.000 pcs memerlukan waktu sebanyak 41,32 menit. Perbedaan waktu penyelesaian dengan stasiun kerja pengepresan telah menunjukkan ketidak seimbangan waktu proses, sehingga perlu adanya perubahan metode kerja untuk menurunkan waktu proses yang ada di stasiun kerja inspeksi. Data tersebut ditunjukkan pada Gambar 1 berikut. 
Tabel 1. Data waktu proses tiap stasiun kerja

\begin{tabular}{|c|c|c|c|}
\hline No & $\begin{array}{c}\text { Incoming } \\
\text { material }\end{array}$ & $\begin{array}{c}\text { Stasiun } \\
\text { Pengepresan }\end{array}$ & $\begin{array}{c}\text { Stasiun } \\
\text { Inspeksi }\end{array}$ \\
\hline 1 & 4.42 & 9,38 & 41.32 \\
\hline 2 & 2.35 & 9,37 & 41.14 \\
\hline 3 & 3.43 & 9,42 & 41.59 \\
\hline 4 & 3.38 & 9,39 & 41.50 \\
\hline 5 & 3.52 & 9,39 & 41.28 \\
\hline 6 & 2.31 & 9,4 & 41.41 \\
\hline 7 & 3.81 & 9,38 & 41.04 \\
\hline 8 & 2.14 & 9,41 & 40.89 \\
\hline 9 & 2.63 & 9,4 & 41.15 \\
\hline 10 & 2.00 & 9,37 & 41.28 \\
\hline 11 & 4.02 & 9,42 & 40.98 \\
\hline 12 & 2.47 & 9,38 & 41.52 \\
\hline 13 & 3.13 & 9,41 & 41.35 \\
\hline 14 & 4.06 & 9,39 & 41.65 \\
\hline 15 & 2.69 & 9,39 & 41.23 \\
\hline
\end{tabular}

\begin{tabular}{|c|c|c|c|}
\hline No & $\begin{array}{c}\text { Incoming } \\
\text { material }\end{array}$ & $\begin{array}{c}\text { Stasiun } \\
\text { Pengepresan }\end{array}$ & $\begin{array}{c}\text { Stasiun } \\
\text { Inspeksi }\end{array}$ \\
\hline 16 & 1.35 & 9,37 & 40.88 \\
\hline 17 & 2.24 & 9,4 & 41.55 \\
\hline 18 & 3.12 & 9,38 & 41.51 \\
\hline 19 & 2.36 & 9,4 & 41.14 \\
\hline 20 & 2.77 & 9,43 & 41.66 \\
\hline 21 & 3.63 & 9,41 & 41.13 \\
\hline 22 & 1.54 & 9,39 & 41.60 \\
\hline 23 & 2.65 & 9,36 & 40.86 \\
\hline 24 & 1.80 & 9,4 & 41.65 \\
\hline 25 & 2.43 & 9,41 & 41.57 \\
\hline 26 & 3.15 & 9,41 & 41.51 \\
\hline 27 & 1.09 & 9,38 & 41.34 \\
\hline 28 & 2.91 & 9,41 & 41.33 \\
\hline 29 & 1.30 & 9,4 & 41.08 \\
\hline 30 & 1.72 & 9,36 & 41.40 \\
\hline
\end{tabular}

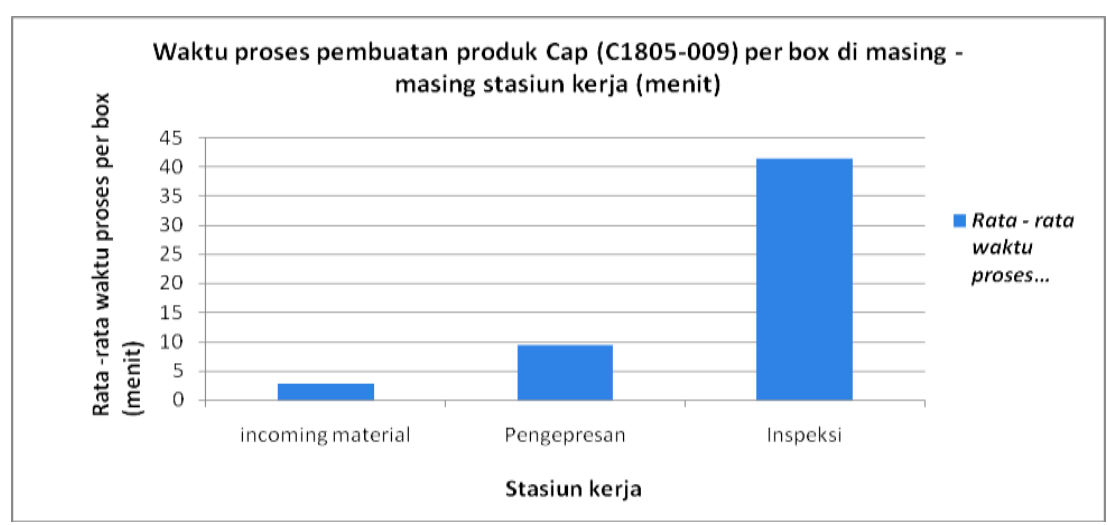

Gambar 1. Waktu proses per box (menit) dimasing - masing stasiun kerja

\subsection{Tata Letak Proses}

Tata letak stasiun kerja pada proses pembuatan produk Cap (C1805-009) yang akan dilakukan penelitaian di tunjukakan pada gambar 2. Alur proses pembuatan produk melewati stasiun incoming material, stasiun kerja pengepresan, stasiun kerja inspeksi dan store finish good. Pada gambar menunjukkan bahwa tata letak stasiun kerja inspeksi berada jauh di luar garis sehingga membutuhkan waktu yang lebih lama untuk menyupai produk WIP (work in proses) ke stasiun kerja inspeksi. Kondisi sekarang jarak antara stasiun kerja pengepresan ke stasiun kerja inspeksi 60-meter ditempuh dengan waktu 6 menit dan jarak dari stasiun kerja inspeksi ke stasiun store finish good 33-meter ditempuh dengan waktu 3 menit. Kondisi ini menunjukkan adanya pemborosan yang harus segera dikurangi atau dihilangkan.

\subsection{Hasil Simulasi Promodel}

Setelah mengumpulkan data waktu proses di setiap stasiun kerja, maka dirancangan model simulasi untuk memodelkan proses produksi saat ini. Hasil model simulasi awal proses pembuatan produk Cap (C1805-009) ditunjukkan pada Tabel 2. Kolom sebelah kiri menunjukkan waktu sistem aktual sistem sekarang sedangkan kolom sebelah kanan merupakan hasil dari model simulasi awal.

Analisis selanjutnya adalah melakukan validasi untuk melihat apakah hasil simulasi sudah sesuai dengan waktu proses aktual saat ini. dibuat sudah dapat mempresentasikan sistem sekarang yang ada. Berdasarkan hasil analisis uji-t berpasangan diketahui bahwa nilai $p$ adalah 0,730 . Hal ini berarti tidak ada perbedaan antara waktu proses aktual dan waktu proses hasil simulasi Promodel. Setelah mendapatkan model yang valid, maka dilanjutkan dengan membuat rancangan perbaikan proses. 


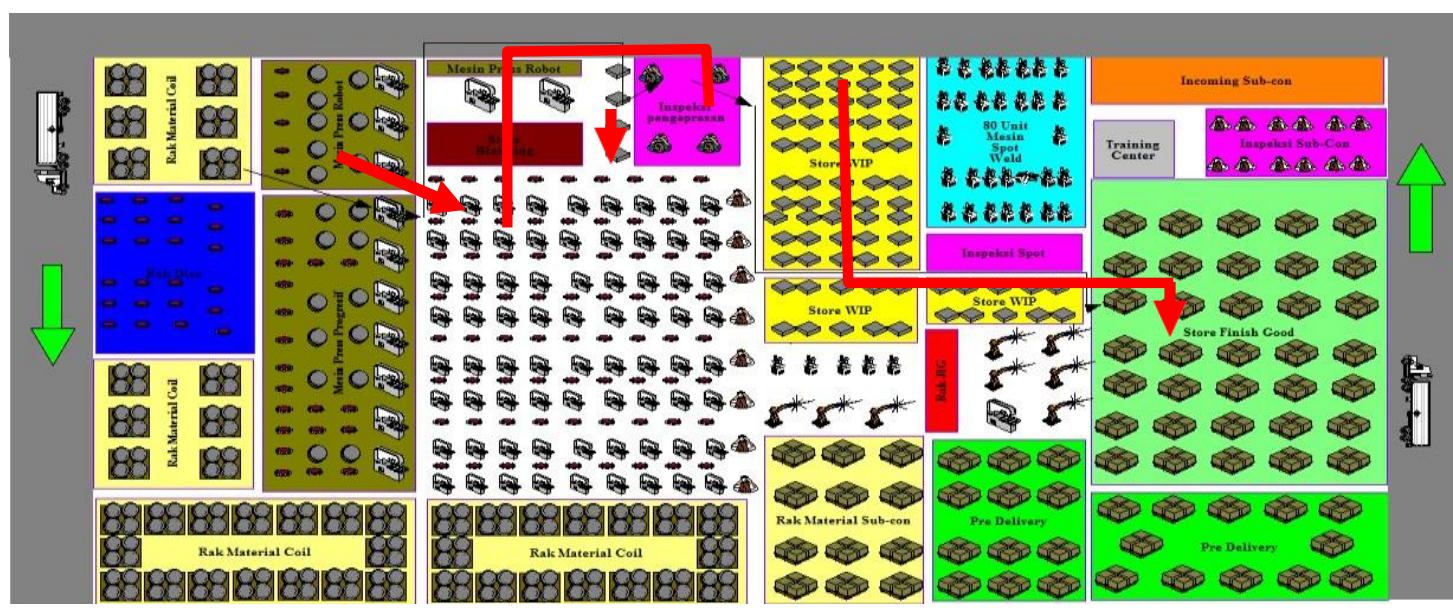

Gambar 2. Layout aktual sistem pembuatan produk Cap (C1805-009)

Tabel 2. Perbandingan Waktu Proses Aktual dan Hasil Simulasi

\begin{tabular}{|c|c|c|}
\hline No & $\begin{array}{c}\text { Sistem } \\
\text { sekarang }\end{array}$ & $\begin{array}{c}\text { Simulasi } \\
\text { awal }\end{array}$ \\
\hline 1 & 41,30 & 41,32 \\
\hline 2 & 41,31 & 41,14 \\
\hline 3 & 41,27 & 41,59 \\
\hline 4 & 41,32 & 41,50 \\
\hline 5 & 41,28 & 41,28 \\
\hline 6 & 41,32 & 41,41 \\
\hline 7 & 41,29 & 41,04 \\
\hline 8 & 41,32 & 40,89 \\
\hline 9 & 41,29 & 41,15 \\
\hline 10 & 41,24 & 41,28 \\
\hline
\end{tabular}

\begin{tabular}{|c|c|c|}
\hline No & $\begin{array}{c}\text { Sistem } \\
\text { sekarang }\end{array}$ & $\begin{array}{c}\text { Simulasi } \\
\text { awal }\end{array}$ \\
\hline 11 & 41,33 & 40,98 \\
\hline 12 & 41,33 & 41,52 \\
\hline 13 & 41,31 & 41,35 \\
\hline 14 & 41,31 & 41,65 \\
\hline 15 & 41,26 & 41,23 \\
\hline 16 & 41,33 & 40,88 \\
\hline 17 & 41,33 & 41,55 \\
\hline 18 & 41,32 & 41,51 \\
\hline 19 & 41,29 & 41,14 \\
\hline 20 & 41,35 & 41,66 \\
\hline
\end{tabular}

\begin{tabular}{|c|c|c|}
\hline No & $\begin{array}{c}\text { Sistem } \\
\text { Sekarang }\end{array}$ & $\begin{array}{c}\text { Simulasi } \\
\text { awal }\end{array}$ \\
\hline 21 & 41,28 & 41,13 \\
\hline 22 & 41,26 & 41,60 \\
\hline 23 & 41,34 & 40,86 \\
\hline 24 & 41,32 & 41,65 \\
\hline 25 & 41,29 & 41,57 \\
\hline 26 & 41,27 & 41,51 \\
\hline 27 & 41,29 & 41,34 \\
\hline 28 & 41,29 & 41,33 \\
\hline 29 & 41,29 & 41,08 \\
\hline 30 & 41,34 & 41,40 \\
\hline
\end{tabular}

\subsection{Usulan Perbaikan Proses}

Pada simulasi awal diperoleh hasil terjadi antrian produk WIP (work in proses) sebanyak 36 box serta jika dilihat dari tata letak stasuin kerja inspeksi yang berada jauh diantara stasiun kerja pengepresan dan area penyimpanan produk jadi mengakibatkan proses pemindahan produk memerlukan waktu sekitar 6 menit. Penumpukan produk yang menunggu proses dan pemindahan produk yang membutuhkan waktu lama adalah pemborosan maka pada penelitian ini akan melakukan perbaikan metode kerja dan perubahan tata letak untuk mempercepat aliran proses di stasiun kerja inspeksi.

Perbaikan metode kerja dilakukan dengan cara pembuatan alat bantu proses. Pembuatan alat bantu ini dikhususkan untuk mengurangi waktu proses inspeksi. Desain alat bantu dan langkah-langkah prosesnya dapat dilihat pada gambar 3 . Ukuran jig panjang $250 \mathrm{~mm}$ x lebar $250 \mathrm{~mm} \times$ tebal mangnet sheet $2 \mathrm{~mm}$ dan tebal cover plastik $0,8 \mathrm{~mm}$. Pada ujung disatukan dengan menggunakan lem. Pemilihan material berdasarkan bentuk dari alat dan harga yang relatif murah.

Langkah - langkah proses kerja inspeksi diawali, produk yang akan dilakukan pengecekan diambil sebagian dan di letakkan diatas meja dan diratakan, dilakukan pengecekan bagian atas atau bagian yang terlihat. Kemudian produk yang sudah dicek dibalik dengan jari (manual tanpa alat). Sedangkan pada langkah perbaikan metode cara membalik produk di bantu dengan menggunakan magnet sheet. Langkah selanjutnya dilakukan pengecekan pada bagian yang belum dilakukan pengecekan. Diakhiri penghitungan jumlah dari produk yang telah dilakukan pengecekan dengan cara di timbang per 2000 pcs atau setara dengan $6.222 \mathrm{~kg}$. Metode ini digunakan untuk mempercepat waktu menghitung produk karena produk yang kecil, jumlah standar kuantitasnya yang banyak untuk menghindari kesalahan hitung kelebihan atau kekurangan jumlah.

Usulan perbaikan yang kedua adalah dengan melakukan perancangan ulang tata letak proses produksi. Tata letak pada proses produksi Cap (C1805-009) saat ini menggunakan produk layout. 
Namun aktual di lapangan pada stasiun kerja inspeksi jaraknya jauh sehingga memerlukan waktu lebih lama untuk mendistribusikan produk yang akan dan setelah diproses. Jarak antar stasiun distribusi yang adalah sebuah pemborosan, pemborosan waktu ini harus di kurangi untuk memperlancar pendistribusian material ke stasiun kerja berikutnya.
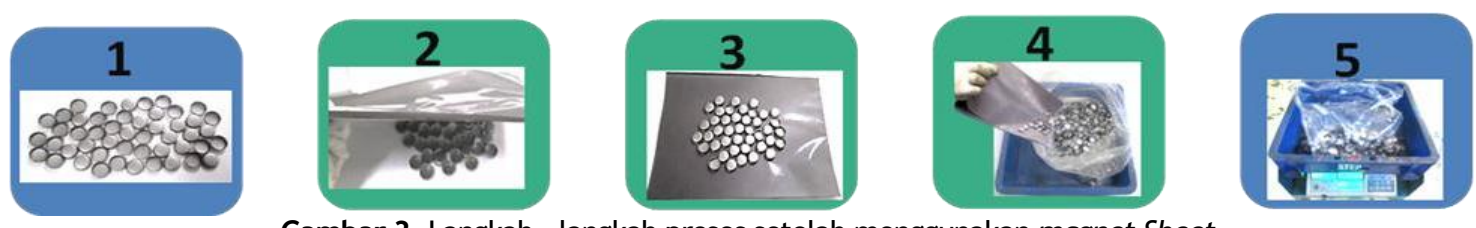

Gambar 3. Langkah - langkah proses setelah menggunakan magnet Sheet

Untuk mengurangi waktu distribusi maka perlu dilakukan perubahan tata letak stasiun kerja inspeksi. Perubahan tata letak stasiun kerja inspeksi pada produksi Cap (C1805-009) yang di tunjukkan pada Gambar 4. Posisi stasiun kerja inspeksi sebelum dilakukan perubahan tata letak berada di paling atas. Pada posisi ini material yang akan menuju stasiun kerja inspeksi harus bergerak menjauh dari arah ke luar melewati mesin pres robot. Jarak dari stasiun pengepresan ke stasiun kerja inspeksi 60 $\mathrm{m}$.

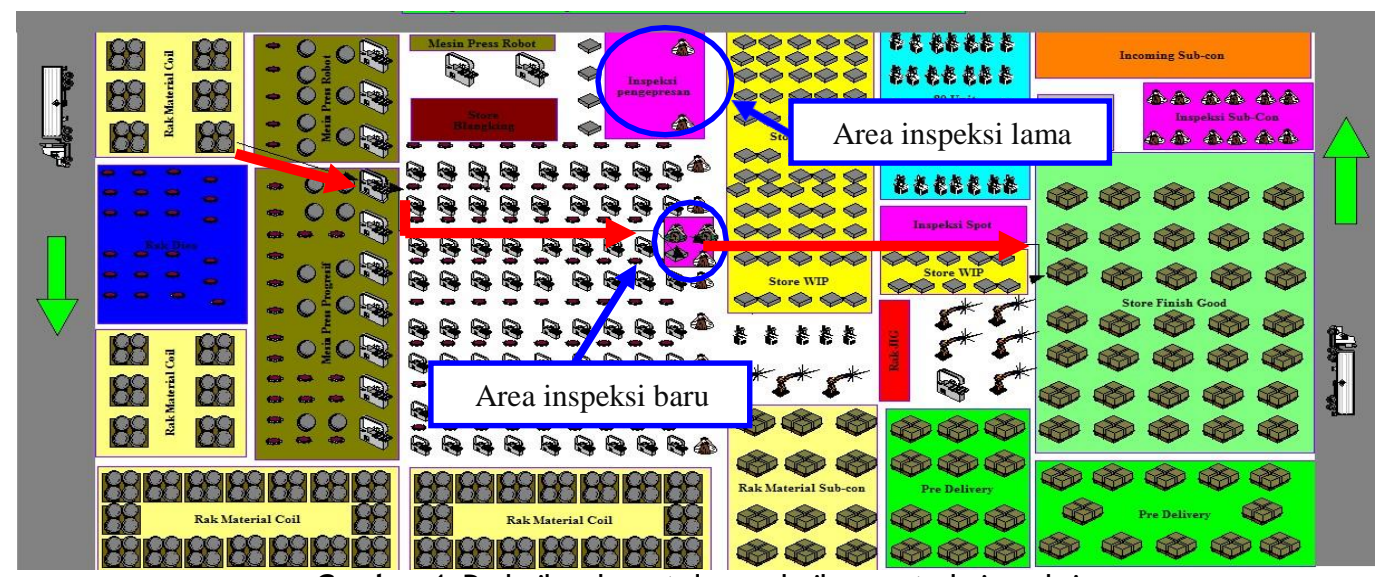

Gambar 4. Perbaikan layout dan perbaikan metode inspeksi

Rencana perubahan tata letak stasiun kerja inspeksi berada di area tengah antara stasiun kerja pengepresan dan area store produk jadi. Pada perubahan tata letak ini dapat mengurangi jarak sebesar $30 \mathrm{~m}$ dari stasiun kerja pengepresan ke stasiun kerja inspeksi dan jarak $13 \mathrm{~m}$ dari stasiun kerja inspeksi ke area penyimpanan produk jadi.

\subsection{Hasil Simulasi Perbaikan Proses}

Untuk dapat melakukan simulasi terhadap perbaikan proses, maka dilakukan terlebih dahulu pengambilan waktu proses. Pengambilan waktu pada perubahan layout ini dilakukan dengan cara perhitungan jarak pada simulasi awal dibandingkan dengan jarak antar stasiun kerja yang dilakukan perbaikan. Jarak aktual dari stasiun kerja pengepresan ke stasiun kerja inspeksi adalah 60 meter, dan jarak dari stasiun kerja inspeksi ke area penyimpanan produk jadi (finish good) adalah 33 meter. Dengan jarak tersebut memerlukan 6 menit untuk memindahkan produk Cap WIP ke stasiun kerja inspeksi dan membutuhkan waktu 3 menit untuk memindahkan produk jadi ke area penyimpanan produk jadi.

Sesuai perubahan layout yang sekarang jarak dari stasiun pengepresan ke layout stasiun kerja inspeksi yang baru adalah 30-meter maka dengan jarak ini membutuhkan waktu sebanyak 3 menit, dan jarak dari stasiun inspeksi yang baru ke area penyimpanan adalah 20 meter maka waktu yang dibutuhkan untuk memindahkan barang jadi ke area penyimpanan yaitu 2 menit. Dengan data tersebut maka dilakukan verifikasi dengan mengambil waktu dari stasiun pengepresan ke area terdekat dari layout yang direncanakan. Dari verifikasi data tersebut terbukti bahwa dari stasiun pengepresan ke stasiun inspeksi yang direncanakan memerlukan waktu 3 menit dan dari stasiun inspekasi ke area penyimpanan membutuhkan waktu 2 menit. Perbandaingan hasil simulasi awal dan setelah melakukan perbaikan metode dan perubahan tata letak ditunjukkan pada Tabel 3. 
Tabel 3. Hasil Simulasi Perbaikan Metode Kerja dan Perubahan Letak

\begin{tabular}{|c|c|c|c|c|c|c|c|c|}
\hline \multirow[t]{2}{*}{ No } & \multirow{2}{*}{ Uraian } & \multirow{2}{*}{$\begin{array}{c}\text { Hasil } \\
\text { simulasi } \\
\text { awal }\end{array}$} & \multicolumn{3}{|c|}{$\begin{array}{l}\text { Hasil simulasi perbaikan } \\
\text { metode inspeksi }\end{array}$} & \multicolumn{3}{|c|}{$\begin{array}{l}\text { Hasil simulasi perubahan layout } \\
\text { dan perbaikan metode inspeksi }\end{array}$} \\
\hline & & & hasil & selisih & 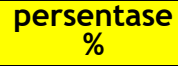 & hasil & selisih & $\underset{\%}{\operatorname{persentase}}$ \\
\hline 1 & $\begin{array}{l}\text { Jumlah } \\
\text { Inspektor(orang) }\end{array}$ & 8 & 4 & 4 & 50,00 & 4 & 4 & 50,00 \\
\hline 2 & $\begin{array}{l}\text { Hasil produksi } \\
\text { (per hari) }\end{array}$ & 64 & 64 & 0 & 0,00 & 64 & 5 & 0,00 \\
\hline 3 & $\begin{array}{l}\text { Waktu proses } \\
\text { inspeksi (menit) }\end{array}$ & 41,3 & 9,59 & 31,08 & 330,66 & 9,59 & 31,71 & 330,66 \\
\hline 4 & $\begin{array}{l}\text { jumlah antrian } \\
\text { (box) }\end{array}$ & 36 & 32 & 4 & 12,50 & 32 & 4 & 12,50 \\
\hline 5 & $\begin{array}{l}\text { Rata - rata waktu } \\
\text { operasi tiap } \\
\text { entitas (menit) }\end{array}$ & 541,95 & 427,49 & 114,46 & 26,77 & 403,9 & 138,05 & 34,18 \\
\hline 6 & $\begin{array}{l}\text { Rata - rata waktu tiap } \\
\text { entitas di dalam sistem } \\
\text { (menit) }\end{array}$ & 713,19 & 594,97 & 118,22 & 19,87 & 565,96 & 147,23 & 26,01 \\
\hline
\end{tabular}

\section{Simpulan}

Penelitian ini bertujuan untuk mengurangi waktu proses pembuatan produk Cap (C1805-009). Perbaikan yang dilakukan adalah melalui perbaikan metode kerja dengan menggunakan alat bantu berupa magnet sheet yang digunakan untuk membalik produk saat melakukan pengecekkan di stasiun kerja inspeksi sehingga mempercepat waktu pengecekkan. Selain itu, waktu proses juga dikurangi melalui perancangan ulang tata letak stasiun kerja inspeksi dengan memperpendek jarak antar stasiun kerja pengepresan, stasiun kerja inspeksi, dan area penyimpanan produk jadi (finishgood).

Berdasarkan hasil simulasi, perbandingan besaran penurunan yang terjadi setelah dilakukan perbaikan metode inspeksi maupun perubahan layout antara lain:

- Total produk yang dihasilkan dari kedua simulasi adalah 64 unit per hari.

- Penurunan waktu distasiun kerja inspekasi sebesar 31,08 menit atau 330,66\%.

- Penurunan jumlah antrian di stasiun inspeksi sebanyak 4-unit atau $12,50 \%$.

- Penurunan rata - rata waktu operasi sebesar 138,05 menit atau 34,18\%.

- Penurunan rata - waktu entitas didalam sistem sebesar 147,23 menit atau 26,01\%.

Hasil penelitian ini menunjukkan pengurangan waktu proses yang signifikan. Namun demikian, diperlukan pengawasan secara berkala terhadap penerapan perbaikan proses ini. Perusahaan juga harus terus melakukan perbaikan berkelanjutan agar dapat berkompetisi dengan perusahaanperusahaan kompetitor dan dapat memberikan kualitas produk dan layanan yang baik kepada pelanggan.

Penelitian selanjutnya dapat dilakukan dengan melihat keseluruhan produk yang diproduksi oleh PT. S. Dengan melalukan simulasi secara keseluruhan, maka dapat dirancang suatu perbaikan proses yang terintegrasi satu dengan lain. Utilitas setiap sumber daya dapat diukur untuk selanjutnya dapat dilakukan perbaikan yang tepat sasaran. Penelitian selanjutnya juga dapat melihat perbaikan metode kerja berdasarkan kajian ergonomi. Hal ini dapat meningkatkan kinerja operator dalam melakukan pekerjaannya.

\section{Daftar Pustaka}

1. Harrel, C. Ghosh, B. \& Bowdwn, R. 2012. Simulasi Using ProModel. New york: McGraw- Hill.

2. Mabert, V. A. dan Jacobs, F. R. 1991 Integrated production systems - Design planing, Control, and Scheduling, 4th Edition., Industrial and Management Press, Institute of Industrial Engineers, Georgia.

3. Shingo, Shigeo, 1990. A Study of the Toyota Production System. USA: Andrew P. Dillon Productivity Press.

4. Wignjosoebroto, S. 1992. Teknik Tata Letak Pabrik dan Pemindahan Bahan. Jakarta: Guna Widya.

5. Wiratno, S. E. Dkk. "Supply Chain Risk menagement”, Universitas Teknologi Yogyakarta, Indonesia. 